\title{
PROFIL SENYAWA BIOAKTIF EKSTRAK KALUS BIJI JERUK PURUT (Citrus hystrix DC.) PASCA INDUKSI METIL JASMONAT
}

\author{
Husnah, Yeni .A ${ }^{1}$, ,Indrianto, Ari' ${ }^{2}$, Tunjung, Woro A.S ${ }^{3}$ \\ ${ }^{1}$ Lab Teknologi Laboratorium Medis Stikes Prima Indonesia \\ ${ }^{2}$ Lab Bioteknologi Fakultas Biologi Universitas Gadjah Mada Yogyakarta \\ ${ }^{3}$ Lab Biokimia Fakultas Biologi Universitas Gadjah Mada Yogyakarta \\ Corresponding Author: \\ Woro Anindito Sri Tunjung, Ph.D \\ e-mail: wanindito@ugm.ac.id
}

\begin{abstract}
Kaffir lime (Citrus hystrix DC.) is an alternative source of potential and relatively safe anticancer compounds as it contains bioactive components. Previous study has shown that the extract of kaffir lime leaves contains terpenoids and potentially as anticancer. However, the content of bioactive compounds may vary due to environmental factors. Callus culture is an alternative method of induction of bioactive compound content with a controlled environment. Previous study has succeeded in inducing callus from kaffir lime seed explants produce the ideal callus with a crumb / friable texture. Methyl jasmonate is reported to induce the production of secondary metabolite compounds. Elicitation with methyl jasmonate is one of the strategy to increase terpenoids from cultured cells Objective of this study is anlyze the using of methyl jasmonate as elicitor.to increase bioactive compounds inkaffir lime cell suspension. Callus induced from seed explants age 40 days were transferred into liquid medium for the initiation of suspension culture. Subculture is done when the age of culture reaches 21 days then measured thegrowth curve of cell supension and concentration of sucrose in medium. After cells reached log phse in 12 days then be treated with methyl jasmonic for 8 days. The cell suspension then beextracted with ethyl acetate by maceration method. The content of bioactive compounds in the extract was anlyzed with GC-MS. Suspension of lime lime cells C. hystrix, without treatment yields fatty acid compounds. Bioactive compounds produced by suspended cell suspension after methyl jasmonate elicitation is germacrene A, myrcene, alpha-terpineol, geranyl acetate, trans-caryophyllene, deltaguaiene and several types of ester fatty acids.
\end{abstract}

Keywords: Citrus hystrix DC., callus, elisitation, bioactive components, cancer

\begin{abstract}
ABSTRAK
Jeruk purut (Citrus hystrix DC.) adalah sumber alternatif senyawa antikanker potensial dan relatif aman karena mengandung komponen bioaktif. Penelitian sebelumnya telah menunjukkan bahwa ekstrak daun jeruk purut mengandung terpenoid dan berpotensi sebagai antikanker. Namun, kandungan senyawa bioaktif dapat bervariasi karena faktor lingkungan. Kultur kalus adalah metode alternatif induksi kandungan senyawa bioaktif dengan lingkungan yang terkontrol. Penelitian sebelumnya telah berhasil menginduksi kalus dari eksplan eksplan biji jeruk dengan teknik kultur jaringan menghasilkan kalus yang ideal dengan tekstur remah / gembur. Metil jasmonat dilaporkan menginduksi produksi senyawa metabolit sekunder. Elisitasi dengan Metil jasmonat adalah salah satu upaya untuk meningkatkan terpenoid dari sel yang dikultur.
\end{abstract}


Penelitian ini bertujuan untuk menerapkan metode elisitasi kalus biji jeruk purut suspensi sel. Menggunakan elisitor metil jasmonat. Kalus diinduksi dari eksplan biji, kalus umur 40 hari ditransfer dalam media cair untuk inisiasi kultur suspensi. Subkultur dilakukan ketika umur kultur mencapai 21 hari kemudian diukur kurva pertumbuhan dan kadar sukrosa dalam medium. Kultur diduga berumur 12 hari akhir fase log dan diperlakukan dengan elisitor metil jasmonat dan dipanen pada hari ke-8. Suspensi sel perlakuan diekstraksi dengan pelarut etil asetat dengan metode maserasi. Kandungan senyawa bioaktif dalam ekstrak diuji dengan GC-MS. Kultur suspensi sel kalus $C$. hystrix, tanpa perlakuan hanya terdeteksi asam lemak. Akan tetapi Senyawa bioaktif yang dihasilkan oleh suspensi sel setelah elisitasi metil jasmonat menghasilkan senyawa adalah germacrene A, myrcene, alpha-terpineol, geranyl acetate, trans-caryophyllene, deltaguaiene dan beberapa jenis asam lemak ester.

Kata kunci: Citrus hystrix DC., kalus, elisitasi, senyawa bioaktif, kanker

\section{PENDAHULUAN}

Prevalensi penyakit kanker di Indonesia cukup tinggi. Berdasarkan data Riset Kesehatan Dasar (Riskesdas) tahun 2013, prevalensi tumor/kanker di Indonesia sebesar 1,4 per 1000 penduduk, atau sekitar 330.000 orang. Kanker tertinggi di Indonesia pada perempuan yakni kanker payudara dan kanker leher rahim. Sedangkan pada laki-laki yakni kanker paru dan kanker kolorektal.

Menurut WHO (2012), angka kematian yang disebabkan oleh kanker payudara di Indonesia menempati urutan ke-10 setelah kanker paru yang menempati urutan ke-9 pada tahun 2012. Kanker payudara merupakan masalah kesehatan masyarakat yang penting dan banyak mendapat perhatian dari ahli medis dunia. Penanganan kanker pada umumnya masih bergantung pada kemoterapi yang berasal dari bahan kimia sintetis. Namun, kelemahan senyawa kimia sintesis tersebut dapat menimbulkan efek multidrug resistance, suatu fenomena dimana sel kanker yang diterapi dengan obat tertentu menjadi resisten terhadap obat-obatan lain yang memiliki struktur dan mekanisme kerja yang hampir sama (Baguley, 2010). Hal tersebut menjadi latar belakang penelitian-penelitian untuk menemukan agen obat herbal baru yang potensial dan relatif aman. Studi penelitian sebelumnya mengenai kandungan bioaktif pada daun jeruk purut mendapatkan bahwa daun jeruk purut mengandung banyak senyawa metabolit sekunder dan beberapa diantaranya terbukti berpotensi sebagai antikanker. Pada ekstrak etil asetat terdapat 21 senyawa bioaktif yang berfungsi sebagai antikanker seperti phytol, palmitic acid, linolenic acid, , $\alpha$-caryophyllene/ $\alpha$-humulene, ethyl palmitate dan neophytadiene. Pada ekstrak kloroform terdapat 13 senyawa yang teridentifikasi sebagai antikanker yaitu palmiticacid/hexadecanoic; heneicosane; neophytadiene; tetradecanoic acid/myristic acid; 9-octadecanoic acid (CAS) dan lainnya. 
Komponen-komponen tersebut diketahui berpotensi sebagai antikanker. Kandungan bioaktif pada daun jeruk purut dapat berubah-ubah dikarenakan faktor lingkungan. Kondisi lingkungan pada pertumbuhan tanaman jeruk purut secara in vivo dapat mempengaruhi kandungan senyawa bioaktif pada tanaman tersebut, Sehingga diperlukan suatu strategi untuk memproduksi senyawa aktif dari tanaman dengan kondisi seragam dan terkontrol yaitu menggunakan teknik kultur jaringan tumbuhan berupa kultur kalus.

Metode yang dapat digunakan untuk menginduksi dan meningkatkan pembentukan metabolit sekunder. Salah satunya adalah metode elisitasi. Elisitasi dapat dilakukan dengan menambahkan elisitor abiotik maupun biotik (Namdeo, 2007). Salah satu elisitor abiotic adalah Metil jasmonat.

Metil jasmonat (MeJA) merupakan senyawa endogen dalam tanaman yang banyak diproduksi dalam kondisi stress. Adanya stress yang disebabkan oleh lingkungan eksternal tanaman menyebabkan terjadinya mekanisme pertahanan tanaman salah satunya dengan pembentukan metabolit sekunder (Muryanti \& Anggarwulan, 2005). MeJA merupakan derivat asam jasmonat yang terbentuk akibat adanya proses metilasi asam jasmonat oleh enzim karboksil metil transferase dalam jalur asam $\alpha$-linolenat (Zhao dkk., 2005). Menurut Flescher et al.
(2010) menunjukkan bahwa elisitasi dengan MeJa dapat meningkatkan senyawa metabolit sekunder.

Induksi pembentukan metabolit sekunder melalui jalur asam jasmonat dengan MeJa sebagai turunannya tidak spesifik pada metabolit tertentu saja, tetapi dapat meningkatkan senyawa metabolit seperti terpenoid, flavonoid, alkaloid, dan fenilpropanoid serta berbagai metabolit

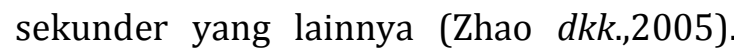
Sehingga, MeJa mempunyai potensi sebagai elisitor yang dapat meningkatkan produksi senyawa metabolit sekunder. Berdasarkan latar belakang masalah di atas, perlu dilakukan penelitian tentang elisitasi dengan menggunakan MeJa yang berpotensi untuk meningkatkan produksi metabolit sekunder alkaloid dalam media MS (Murashige dan Skoog) secara in vitro.

\section{METODE}

\section{Waktu dan Tempat}

.Sampel jeruk purut diperoleh di kebun jeruk purut di Kali Duren Candirejo Borobudur Magelang, Jawa Tengah. Induksi kalus, kultur suspensi dan elisitasi menggunakan MeJa dilakukan di Laboratorium Bioteknologi dan Biokimia Fakultas Biologi Universitas Gadjah Mada Yogyakarta. Uji senyawa bioaktif dengan GCMS dilakukan di Laboratorium Kimia Fakultas Matematika dan Ilmu Pengetahuan Alam (FMIPA) Universitas Universitas Gadjah Mada Yogyakarta. 


\section{A. Teknik Pengumpulan Data}

\section{Koleksi Biji Jeruk Purut}

Biji jeruk purut dikoleksi dari kebun jeruk purut di Kali Duren Candirejo Borobudur Magelang, Jawa Tengah. Pada penelitian ini dipilih biji jeruk purut yang berasal dari buah yang usianya dewasa (kulit berwarna kehijauan dan buah berukuran sedang) dengan usia tanaman adalah 3 bulan. Hal ini dikarenakan biji dengan kriteria tersebut masih dalam fase pertumbuhan dan masih banyak senyawa bioaktif yang diproduksi dalam rangka sistem pertahanan.

\section{Induksi Kalus Jeruk Purut (Citrus histrix} DC.)

a. Pembuatan Medium basal MS . Tahap pertama adalah tahap persiapan pembuatan medium MS berdasarkan metode Indrianto $d k k$.(2014) dengan modifikasi. Sebelumnya disiapkan larutan stok mikronutrien mikronutrien, besi, dan vitamin. Sementara itu komponen makronutrien dibuat dengan melarutkan bahan-bahan makronutrien untuk MS 1L dalam gelas beker yang berisi $500 \mathrm{ml}$ akuades dengan magnetik stirrer. Larutan stok besi sebanyak $5 \mathrm{ml}$, stok mikronutrien sebanyak $1 \mathrm{ml}$, dan stok vitamin $4 \mathrm{ml}$ ditambahkan dalam gelas piala. Lalu myoinositol $100 \mathrm{mg}$, dan sukrosa sebanyak 30gram dilarutkan dan dimasukkan dalam gelas beker. Kemudian ditambahkan akuades sampai volume 1 liter. ZPT ditambahkan yaitu auksin 2,4 D 1 ppm dan sitokinin BAP 0,5 ppm. Langkah terakhir sebelum disterilisasi dengan autoklaf yaitu di cek pHnya denganpH meter dan diukur dalam batas $\mathrm{pH}$ 5,6-6,3. Agar sebanyak 10gram ditimbang dan dimasukkan dalam gelas beker, lalu dipanaskan sampai mendidih sambil diaduk sampai agar larut. Setelah larut medium siap dituang dalam botol medium kultur dan ditutup rapat dengan aluminium foil. Botol-botol medium kemudian disterilisasi pada suhu $121^{\circ} \mathrm{C}$ selama 15 menit dengan tekanan 15 Psi.

b. Penanaman Eksplan dalam Medium. Biji jeruk purut yang akan diinduksi menjadi kalus sebelumnya disterilkan. Biji disterilisasi menggunakan metode Ramdan et al. (2014) dengan modifikasi. Biji dimasukkan kedalam Erlenmeyer kemudian direndam dalam klorox 5,25\% dan digoyang selama 5 menit. Biji kemudian dibilas dua kali dengan menggunakan aquades masing-masing dilakukan selama 5 menit. Biji yang sudah steril kemudian ditiriskan dalam kertas saring yang diletakkan pada petridish. Biji dipotong membujur menjadi dua bagian sama besar. Selanjutnya, biji siap ditanam pada medium MS padat yang telah disiapkan. Dalam satu botol kultur medium, ada enam biji jeruk purut yang ditanam dengan rapi dan dipastikan menyentuh medium agar terjadi kontak antara biji dengan medium. Setelah selesai, botol kultur diseal dan dilabeli sesuai tanggal dan 
jenis ZPT yang digunakan dan dibawa ke ruang inkubator untuk disimpan. Semua botol kultur tersebut ditutup dengan kain gelap dan diamati pertumbuhan dan perkembangannya serta diperhatikan tentang adanya kontaminan berupa bakteri dan jamur.

\section{Kultur Suspensi Kalus Jeruk Purut}

a. Pembuatan Kurva Pertumbuhan dari Suspensi Sel Kalus. Hasil optimasi medium untuk mendapatkan medium yang paling baik untuk pertumbuhan sel adalah medium MS tanpa agar dengan komposisi zat pengatur tumbuh sama dengan induksi kalus padat jeruk purut. Suspensi kalus yang diperoleh akan digojog terus selama 3 mingggu dan dilihat ada endapan yang menempel pada dinding Erlenmeyer. Endapan yang menempel tersebut merupakan pektin yang ada pada kultur sel kalus hasil dari kontak media dengan sel. Semakin banyak endapan yang tertinggal dan melekat pada dinding, semakin banyak pula sel kalus yang diperoleh.

\section{b. Pengukuran Kadar Sukrosa Media} Kultur Suspensi Kalus. Pengukuran kadar sukrosa dalam medium kultur dilakukan secara berkala setiap 4 hari mengikuti pengukuran kurva pertumbuhan kultur suspensi. Pengukuran sukrosa dilakukan dengan metode Asam Fenol Sulfat. Gula sederhana seperti sukrosa dapat dideteksi dengan fenol dalam asam sulfat pekat yang akan menghasilkan warna jingga kekuningan yang stabil. Larutan standar dibuat dengan pengenceran seri medium suspensi yaitu konsentrasi 30.000, 12.000, $6.000,3.000,1.500,300,150$, dan 0 ppm. Media cair suspense masing-masing dengan konsentrasi tersebut diambil sebanyak 0,5 mL kemudian dipindahkan kedalam tabung reaksi dan di seal dengan rapat. Larutan fenol 5\% ditambahkan sebanyak 0,5 mL dan ditambahkan $\mathrm{H}_{2} \mathrm{SO}_{4}$ pekat sebanyak 2,5 mL melalui dinding tabung dengan hati-hati. Larutan kemudian didiamkan selama 10 menit, kemudian divortek dan didiamkan lagi selama 20 menit. Absorbansi larutan diukur menggunakan spektrofotometer pada panjang gelombang $490 \mathrm{~nm}$ kemudian dibuat persamaan liniernya menggunakan kurva standar. Persamaan linier digunakan sebagai rumus untuk menghitung konsentrasi sukrosa sampel yang diketahui nilai absorbansinya. Sampel dengan umur $0,4,8,12,16,20,24$, dan 28 hari diambil sebanyak $0,5 \mathrm{~mL}$ dan dimasukkan kedalam tabung reaksi. Proses selanjutnya sama dengan pembuatan larutan standar. Absorbansi sampel yang telah diketahui dimasukkan kedalam rumus persamaan linier dan dihitung sebagai konsentrasi sukrosa dalam sampel.

\section{c. Induksi MeJa dalam Kultur Suspensi}

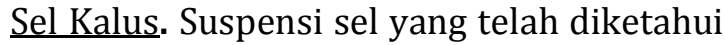
fase pertumbuhannya siap dielisitasi dengan metil jasmonat pada hari ke-12 (akhir fase log). Konsentrasi metil jasmonat 
(98\%) yang ditambahkan dalam kultur suspensi kalus jeruk purut adalah 0,05;0,5; 5; dan $50 \mathrm{mM}$. Metil jasmonat yang dimasukkan dalam botol kultur sebelumnya dilarutkan dengan ethanol $70 \%$ sampai homogen. Perhitungan konsentrasi metil jasmonat yang dimasukkan dalam botol kultur dapat dilihat pada Lampiran 1.Kultur suspensi sebanyak $50 \mathrm{~mL}$ dalam satu botol medium ditambahkan dengan metil jasmonat yang sudah dilarutkan dengan ethanol $70 \%$ selanjutnya digoyang secara perlahan sampai homogen. Hal tersebut dilakukan di dalam LAF (laminar air flow) dan dalam kondisi steril. Kultur suspensi yang telah dielisitasi metil jasmonat selanjutnya di shaker dengan kecepatan 100 rpm selama 8 hari pengamatan.

\section{Pengamatan sel kultur suspensi selama}

\section{elisitasi}

Pengamatan sel kultur suspensi meliputi morfologi dan densitas sel. Pengamatan morfologi sel suspensi jeruk purut dilakukan sebelum dan selama elisitasi. Sebelum elisitasi, sel suspensi diberi larutan pewarna tripan blue dan Natt\&Herrick. Pewarna Natt\&Herrick digunakan untuk mewarnai nukleus dan organel sel, sedangkan tripan blue digunakan untuk mewarnai sitoplasma sel. Kultur suspensi dalam botol kultur diambil sebanyak 0,5 $\mathrm{mL}$ kemudian dimasukkan dalam mikrotube. Sebanyak 3-4 tetes kultur suspensi kalus jeruk purut diteteskan pada gelas benda kemudian ditambahkan 2 tetes larutan pewarna masing-masing. Selanjutnya diamati dengan menggunakan mikroskop.

Pengamatan densitas sel dilakukan selama elisitasi berlangsung, yaitu mulai hari ke-0 sampai hari ke-8. Suspensi sel diambil dari botol kultur sebanyak 0,5 mL (pengambilan dilakukan dengan menggoyang-goyangkan botol kultur agar homogen dan tanpa diendapkan) menggunakan pipet secara aseptis kemudian dimasukkan dalam mikrotube 1,5 mL. Jumlah sel kemudian dihitung dengan menggunakan haemocytometer dengan 4 ulangan perhitungan. Perhitungan sel dilakukan terhadap sel kultur suspensi jeruk purut dengan bentuk bulat, koma dan panjang.

\section{Ekstraksi dan Uji GC-MS Kultur Suspensi} Kalus

Kultur suspensi yang telah selesai dielisitasi kemudian disaring dengan menggunakan nilon filter ukuran T61. Sel yang telah disaring kemudian dikeringkan dalam ovensuhu $50^{\circ} \mathrm{C}$ sampai diperoleh berat konstan. Sel yang telah kering kemudian dipisahkan dari nilon filter dan digerus menggunakan mortar dan alu hingga halus menjadi serbuk sel. Serbuk sel kemudian dipindahkan dalam botol flakon. Proses ekstraksi dilakukan dengan metode maserasi dengan pelarut etil asetat dengan 
perbandingan serbuk sel kalus 0,1gram:5mL pelarut etil asetat. Serbuk kering dalam botol flakon direndam dalam pelarut etil asetat dan dishaker dengan kecepatan $100 \mathrm{rpm} \pm 24$ jam. Ekstrak kemudian dimasukkan ke dalam mikrotube $2 \mathrm{ml}$ dan kemudian ditimbang. Ekstrak akan digunakan untuk uji GC-MS dan uji sitotoksik disimpan dalam refrigerator suhu $4^{\circ} \mathrm{C}$.

Analisis GC-MS dengan pelarut 95\% dimethyl polysiloxane dan 5\% diphenyl polysiloxane dan gradien suhu kolom awal $50^{\circ} \mathrm{C}$ selama 5 menit, kemudian dinaikkan hingga $260{ }^{\circ} \mathrm{C}$. Suhu detektor yang digunakan adalah $305^{\circ} \mathrm{C}$, dengan pengaturan energi elektron detektor MS sekitar $70 \mathrm{eV}$ dan suhu sumber ion $250^{\circ} \mathrm{C}$. Adapun fase gerak yang digunakan adalah gas Helium.

\section{B. Analisis Data}

Data pengamatan yang diperoleh diolah menggunakan software SPSS dengan dilakukan analisis Anava dan dilanjutkan uji DMRT pada taraf 95\% $(\alpha=0,05)$ dan hasilnya ditampilkan dalam bentuk tabel, grafik, maupun histogram.

\section{HASIL DAN PEMBAHASAN}

\section{A. Kalus biji jeruk purut (Citrus hystrix DC.)}

Eksplan biji yang sudah siap dikupas hingga bersih dan ditanam pada media induksi kalus yaitu ada media MS dan ZPT
BAP:2,4D(0,5). Kalus yang sudah berusia 40 hari siap untuk dipanen. Kalus yang diperoleh berupa kalus berjenis friable dengan tekstur remah. Kalus friable mampu menginduksi beberapa jenis senyawa metabolit sekunder (Aini, 2009). Kalus friable inilah yang akan dijadikan sumber untuk produksi kultur sel pada penelitian
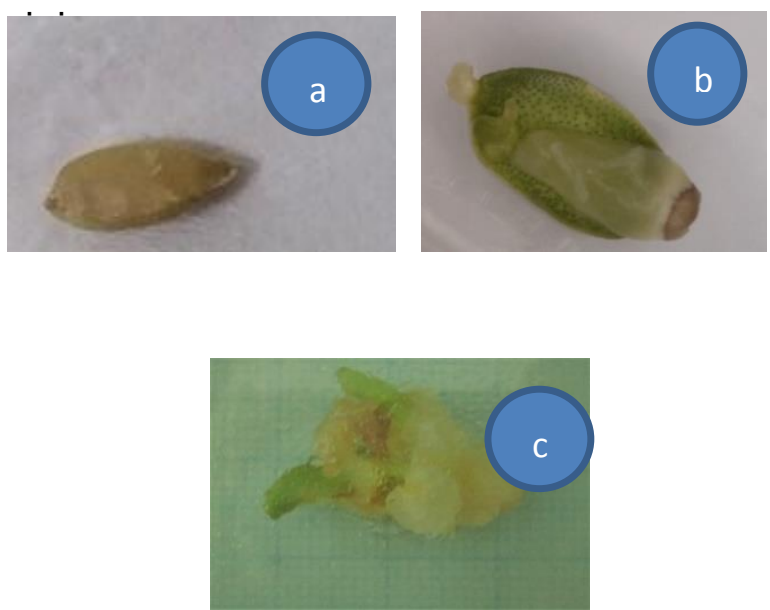

Gambar 1. Biji jeruk purut sumber eksplan kalus (a) induksi kalus usia 7 hari (b) Kalus biji jeruk purut usia 40 hari (c). (Sumber: Pribadi)

\section{B. Kultur suspensi kalus biji jeruk purut} (Citrus hystrix DC.)

Berdasarkan hasil pengukuran kurva pertumbuhan kultur suspensi kalus biji jeruk purut diperoleh hasil berupa grafik (Gambar 2).

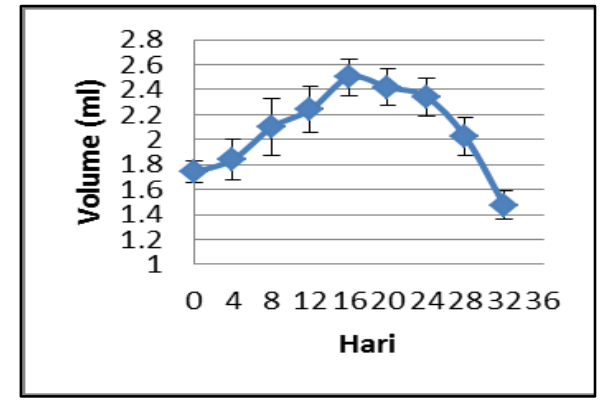

Gambar 2. Kurva pertumbuhan kultur sel kalus jeruk purut (Citrus hystrix DC.). (Sumber: Pribadi) 
Hasil penelitian menunjukkan bahwa fase lag terjadi pada saat sel berumur 0-4 hari. Ketika umur 4-12 hari sel berada pada fase eksponensial. Fase stasioner terjadi pada sel yang berumur lebih dari 16 hari. Hal ini hampir sama dengan kurva tumbuh kultur sel tembakau yang memasuki fase stasioner pada umur lebih dari 15 hari (Collin \& Edward 1998). Menurut Haq (2004), kultur suspensi sel dapat menghasilkan senyawa bioaktif seperti yang dihasilkan oleh tumbuhan asalnya. Sesuai teori sel dari Schleiden dan Schwan yang menyatakan bahwa sel tumbuhan mempunyai totipotensi sehingga sel mampu berkembang atau menghasilkan hasil metabolit sekunder seperti yang dihasilkan oleh induknya.

\section{Kadar Sukrosa Medium Suspensi kultur kalus biji jeruk purut}

Secara umum, penurunan konsentrasi gula menunjukkan bahwa terjadi pertumbuhan sel dimana sel yang sedang aktif tumbuh akan mengkonsumsi komponen dalam media yang salah satu diantaranya mengandung gula. Penurunan konsentrasi gula juga membuktikan bahwa terjadi proses metabolisme sel didalam media. Oleh karena itu, dilakukan pengukuran kadar sukrosa untuk mengetahui pengaruh pertumbuhan sel terhadap konsentrasi gula dalam media.

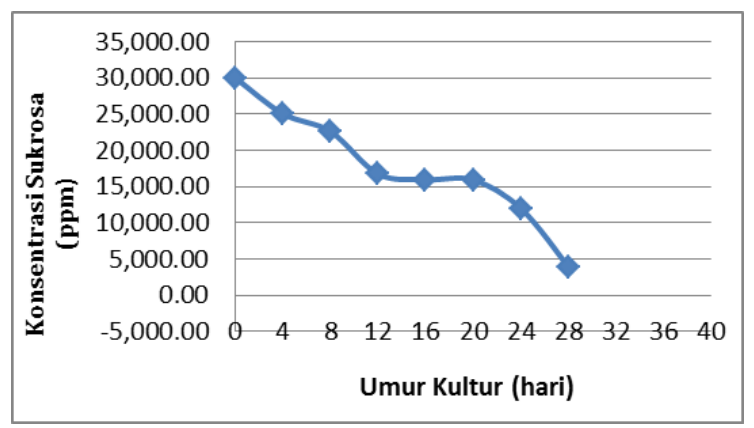

Gambar 3. Konsentrasi sukrosa medium kultur suspense jeruk purut (Citrus hystrix D.C).

Pada hari ke-0 kandungan sukrosa dalam medium adalah 30.000 ppm. Pada hari berikutnya kadar sukrosa masih cukup tinggi, hingga hari ke-8. Pada saat tersebut, komponen gula masih cukup tersedia banyak dalam medium dikarenakan sel-sel masih dalam kondisi stabil dalam hal pembelahan sel. Penurunan kadar sukrosa terjadi mulai hari ke-4 hingga ke-12, pada hari ke-12 konsentrasi sukrosa yaitu 15.000 ppm. Penurunan yang signifikan dimungkinkan karena sel kalus sudah mulai aktif membelah dan melakukan proliferasi menuju proses diferensiasi sel.

\section{Respon sel suspensi jeruk purut terhadap pemberian Metil Jasmonat}

Pada penelitian ini digunakan MeJa dengan konsentrasi $0,05 \mathrm{mM}$; 0,5 mM; 5 $\mathrm{mM}$ dan $50 \mathrm{mM}$. Pada penelitian ini dilakukan induksi MeJa pada usia kultur 12 hari. Pada saat tersebut, kultur dalam fase log, yaitu fase dimana sel-sel aktif untuk melakukan pertumbuhan. Sehingga optimasi produksi metabolit sekunder dimungkinkan terjadi pada saat fase tersebut. 
Tabel 1. Jumlah sel setelah pemberian metil jasmonat

\begin{tabular}{|c|c|c|c|c|c|c|c|c|c|c|}
\hline & \multirow{3}{*}{$\begin{array}{c}\text { KONSENTRASI } \\
\text { METIL JASMONAT }\end{array}$} & \multicolumn{9}{|c|}{ JUMLAH SEL HARI KE- } \\
\hline & & \multicolumn{3}{|c|}{ BENTUK BULAT } & \multicolumn{3}{|c|}{ BENTUK KOMA } & \multicolumn{3}{|c|}{ BENTUK PANJANG } \\
\hline & & 0 & 4 & 8 & $\mathbf{0}$ & 4 & 8 & $\mathbf{0}$ & 4 & 8 \\
\hline 1 & Kontrol & 110 & 53 & 133 & 36 & 30 & 52 & 7 & 9 & 17 \\
\hline 2 & $0,05 \mathrm{mM}$ & 148 & 142 & 180 & 21 & 45 & 46 & 10 & 15 & 29 \\
\hline 3 & $0,5 \mathrm{mM}$ & 76 & 111 & 153 & 19 & 39 & 28 & 9 & 23 & 20 \\
\hline 4 & $5 \mathrm{mM}$ & 43 & 70 & 33 & 23 & 29 & 9 & 8 & 10 & 15 \\
\hline 5 & $50 \mathrm{mM}$ & 8 & 4 & 2 & - & 1 & 3 & 1 & 12 & 6 \\
\hline
\end{tabular}

Kultur yang telah diberikan MeJa diamati selama 8 hari, dan setiap hari selama 8 hari dilakukan pengamatan sel. Berdasarkan tabel 1. diperoleh informasi bahwa kultur suspensi sel jeruk purut didominasi oleh sel bentuk bulat, selanjutnya bentuk koma dan terakhir bentuk panjang. Sel kultur suspensi kalus jeruk purut pada awal fase pertumbuhan didominasi oleh bentuk bulat, setelah beberapa waktu maka sel akan didominasi oleh bentuk panjang. Dimana sel bentuk bulat adalah sel meristematik dan bentuk panjang dan koma adalah sel yang telah mengalami diferensiasi.

Pada penelitian ini diperoleh hasil bahwa jumlah sel yang berbentuk bulat, koma dan panjang mulai dari konsentrasi rendah hingga konsentrasi tertinggi mengalami penurunan. Hal tersebut ditunjukkan oleh Tabel 1, bahwa terjadi penurunan yang signifikan ketika MeJa diberikan dengan dosis tertinggi yaitu $50 \mathrm{mM}$. Hal tersebut dimungkinkan dosis tinggi MeJa memberikan efek letal terhadap populasi sel kultur suspensi kalus jeruk purut.

MeJa merupakan salah satu yang banyak digunakan. MeJa merupakan turunan dari asam jasmonat yaitu senyawa alami yang disintesis oleh tumbuhan sebagai respon terhadap adanya serangan pathogen. MeJa berperan dalam menginisiasi transkripsi gen-gen yang terlibat dalam mekanisme pertahanan pada tumbuhan.Senyawa ini merupakan senyawa pengatur penting yang mempengaruhi respon dan signal tumbuhan yang bekerja dalam penghambatan atau aktivasi suatu hubungan (Norbert et al., 2007). Hasil akhir dari proses ini adalah peningkatan produksi senyawa metabolit sekunder terutama senyawa yang terlibat dalam mekanisme pertahanan pada tumbuhan (Gundlach et al., 1992). Hal ini menjadi dasar penggunaan MeJa sebagai elisitor pada berbagai kultur in vitro tanaman dalam rangka peningkatan produksi metabolit sekunder 
Suspensi sel kalus jeruk purut memiliki bentuk yang bermacam-macam. Terdapat 3 jenis bentuk sel, yaitu bulat, koma dan panjang. Suspense sel kalus jeruk purut memiliki variasi bentuk dikarenakan proses diferensiasi sel, dimana sel mulai menuju spesifitasnya masing-masing untuk membentuk suatu fungsi tertentu yaitu jaringan. Pada Gambar 4. dapat diketahui bahwa sel dengan bagian dalam berbentuk bulat terpulas warna gelap merupakan sel dengan inti. Sedangkan bagian sel yang tidak terpulas gelap menunjukkan bahwa sel tidak memiliki inti (mati).

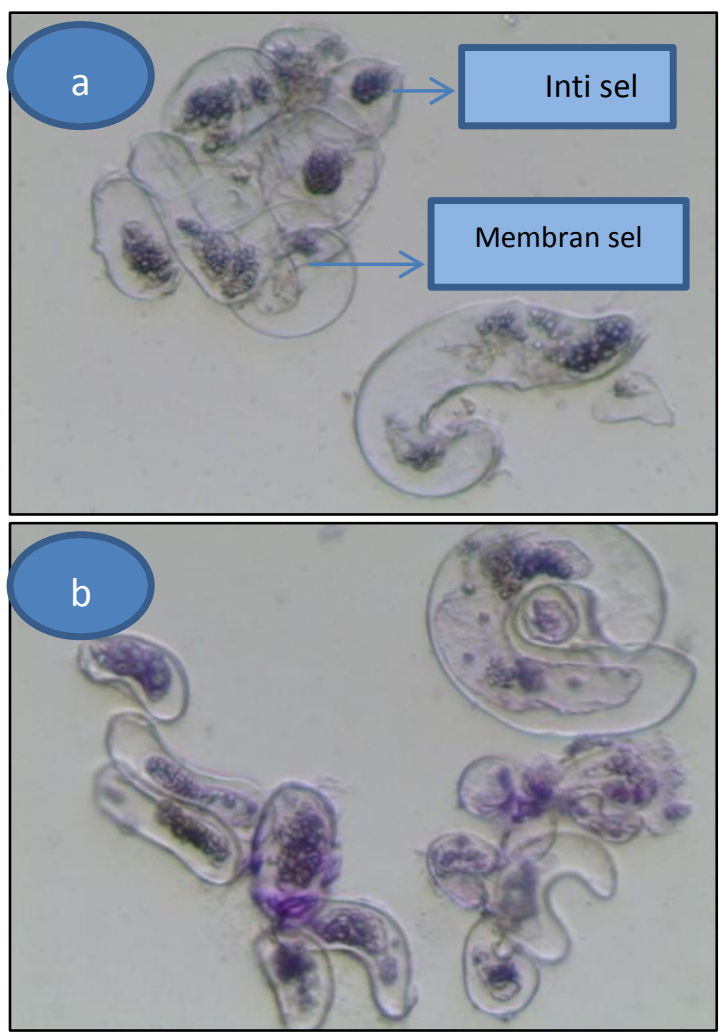

Gambar 5. Kultur suspensi kalus jeruk purut dengan pewarnaan Tripan blue (a) dan pewarnaan Natt \& Herrick (b) perbesaran mikroskop 10x.

Pewarnaan sel dengan menggunakan larutan tripan blue bertujuan untuk membedakan sel yang hidup dan yang mati.
Sel yang mati akan terlihat berwarna biru, karena mengalami lisis sehingga protein dalam plasmanya akan berikatan dengan tripan blue sehingga sel menjadi berwarna biru. Selain itu, sel yang mati akan terlihat berwarna lebih gelap dan bentuknya tidak bulat lagi atau menyusut karena isi sel (sitoplasmanya) keluar. Hal ini tidak terjadi pada sel yang hidup karena tidak mengalami kerusakan pada membran selnya, sehingga sel yang hidup masih terlihat berbentuk bulat, lebih terang dan jernih (Djajanegara, 2009). Metode pewarnaan sel lainnya yaitu Natt and Herrick, prinsip metode pewarnaan ini adalah memperjelas batas bagian sel yaitu batas antara membran sel dengan inti selnya.

\section{E. Profil senyawa bioaktif ekstrak kultur supensi jeruk purut hasil elisitasi dengan metil jasmonat (MeJa)}

Kultur suspensi jeruk purut yang diberi perlakuan elisitor MeJa diasumsikan mampu menghasilkan senyawa pertahanan berupa metabolit sekunder. Sel-sel suspensi kemudian di panen pada hari ke-4 dan ke-8 setelah perlakuan. Sel-sel suspensi kemudian dikeringkan dengan oven dan diekstraksi dengan metode maserasi menggunakan pelarut etil asetat. Ekstrak yang diperoleh digunakan sebagai bahan untuk uji kandungan senyawa bioaktif dengan GC-MS .

Analisis dilakukan terhadap suspensi sel kontrol (tanpa perlakuan) yang dipanen pada umur 20 hari (setara dengan suspensi sel dengan perlakuan elisitor yang dipanen pada hari ke-4 setelah perlakuan), suspensi 
sel dengan perlakuan elisitor $0,05 \mathrm{mM}, 0,5$ $\mathrm{mM}, 5 \mathrm{mM}$ dan $50 \mathrm{mM}$ yang dipanen pada hari ke-4 dan ke-8 setelah perlakuan. Analisis profil senyawa bioaktif suspensi sel jeruk purut dilakukan dengan menggunakan teknik Gas Chromatography Mass Spectrometry (GCMS). Fase gerak yang digunakan adalah gas helium (He) dengan pertimbangan gas ini bersifat inert, murni, tidak mudah terbakar dan mempunyai konduktifitas panas yang tinggi (Hutami, 2009). Jenis kolom yang digunakan adalah kolom kapiler AGILENT HP5 MS yang bersifat non polar dengan komposisi 95\% dimethyl polysiloxane dan 5\% diphenyl polysiloxane. Proses pemisahan senyawa didalam kolom berdasarkan prinsip "like dissolve like", senyawa-senyawa yang bersifat sama dengan kolom akan tertahan lebih lama dan memiliki waktu retensi yang lebih lama. Selain karena polaritas dan interaksinya dengan fase diam, pemisahan didalam kolom juga terjadi karena perbedaan titik didih. Senyawa yang memiliki titik didbe lebih rendah akan memiliki waktu retensi yang lebih singkat.

Mass-Spectrometer merupakan detektor yang menangkap dan mengidentifikasi ion molekul dan fragmentasinya. Ion molekul dapat terbentuk karena adanya elektron yang ditembakkan dan menabrak senyawa hasil separasi GC. Ion molekul dapat terfragmentasi dengan pola tertentu. ion molekul dan fragmen ionnya akan bergerak melalui analyzer (Hutami, 2009). Ion yang memiliki massa lebih kecil akan bergerak lebih dahulu sehingga terdeteksi lebih awal. Oleh karena itu, dalam spektrum massa ion molekul terletak pada bagian akhir spektrum massa.

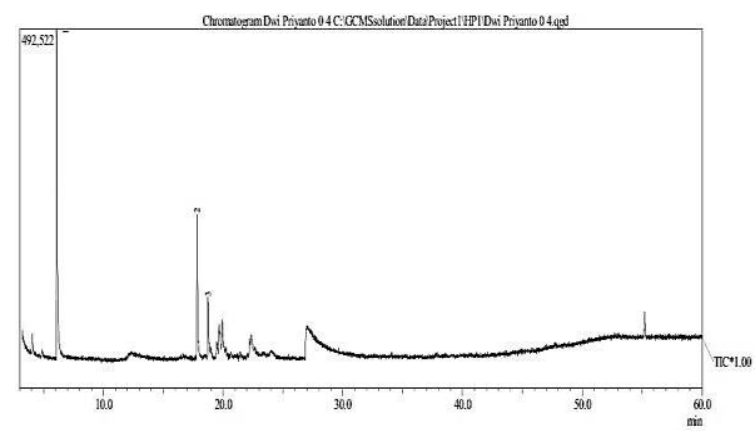

Gambar 7. Kromatogram ekstrak etil asetat suspensi sel jeruk purut (Citrus hystrix DC.) umur 20 hari tanpa perlakuan.

Gambar 7 menunjukkan kromatogram hasil analisis GC-MS terhadap ekstrak suspensi sel jeruk purut tanpa perlakuan yang dipanen pada umur 20 hari (kontrol perlakuan).Terdapat 3 peak pada kromatogram yang menunjukkan adanya tiga senyawa yang terdeteksi terdapat pada ekstrak kontrol perlakuan.

Hasil identifikasi senyawa bioaktif yang terdeteksi dari ekstrak suspensi sel jeruk purut untuk kontrol perlakuan mendapatkan 3 jenis senyawa yang diduga adalah eucalyptol (sinonim 1,8-cineole), betacaryophyllene dan alpha-humulene (sinonim alpha-caryophyllene). Ketiga senyawa ini diketahui juga terdapat pada kultur kalus jeruk purut. 1,8-cineole terdeteksi pada kalus umur 40 hari sedangkan caryophyllene merupakan senyawa yang terdeteksi pada kalus umur 60 hari. 
Kultur suspensi jeruk purut berasal dari kalus umur 40 hari yang diinokulasikan kedalam medium cair. Hasil analisis GC-MS yang ditunjukkan tabel 2 memberikan informasi bahwa senyawa 1,8-cineole tetap diproduksi oleh sel jeruk purut meskipun sel tersebut berada dalam lingkungan fisik yang berbeda. Senyawa caryophyllene yang diproduksi oleh suspensi sel jeruk purut dapat dibedakan menjadi bentuk alphacaryophyllene dan beta-caryophyllene. Pada kalus, senyawa ini baru ditemukan setelah kalus berumur 60 hari. Kultur suspensi yang digunakan dalam penelitian ini berasal dari kalus umur 40 hari yang digojog selama \pm 3 minggu kemudian di subkultur lagi hingga berumur 20 hari. Total umur sel jeruk purut yang berada dalam medium kultur suspensi menjadi \pm 81 hari sehingga deteksi senyawa caryophyllene pada kultur suspensi sangat dimungkinkan.

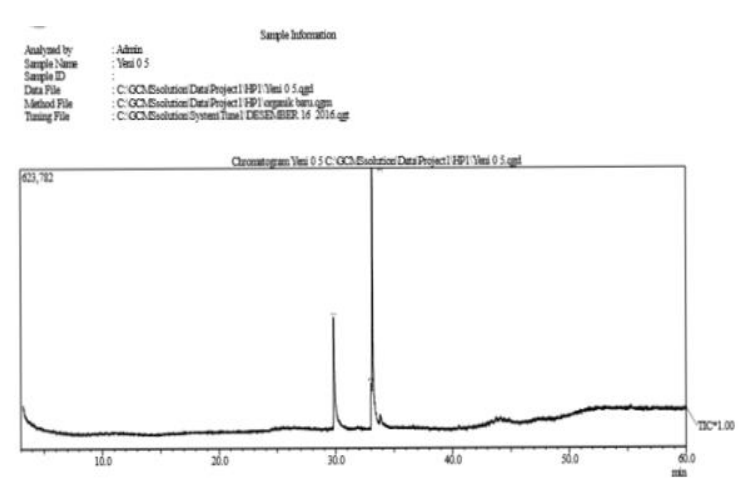

Gambar 8. Kromatogram ekstrak etil asetat suspensi sel jeruk purut (Citrus hystrix DC.) elisitasi metil jasmonat $0,5 \mathrm{mM} ; 8$ hari perlakuan.
Gambar 8. menunjukkan hasil kromatogram ekstrak etil asetat suspensi sel jeruk purut (Citrus hystrix DC.) dengan penambahan elisitor MeJa konsentrasi 0,5 mM kemudian digojog sampai 8 hari tanpa berhenti. Berdasarkan kromatogram pada gambar 12 diperoleh adanya 3 peak yang muncul pada hasil GC-MS yang merupakan hasil senyawa dengan elisitasi MeJa konsentrasi $0,5 \mathrm{mM}$ selama 8 hari berturutturut.

Tabel 3. Profil senyawa bioaktif hasil analisis GC-MS ekstrak etil asetat suspensi sel jeruk purut (Citrus hystrix DC.) perlakuan MeJa konsentrasi 0,5 mM dan waktu panen hari ke-8 setelah perlakuan.

\begin{tabular}{cccll}
\hline $\begin{array}{c}\text { Peak } \\
\text { Area } \\
\text { (\%) }\end{array}$ & $\begin{array}{c}\text { SI } \\
\text { (\%) }\end{array}$ & $\begin{array}{c}\text { No. } \\
\text { Peak }\end{array}$ & $\begin{array}{c}\text { Nama } \\
\text { Senyawa }\end{array}$ & Golongan \\
\hline 31.39 & 95 & 1 & $\begin{array}{l}\text { Hexade- } \\
\text { canoid acid }\end{array}$ & $\begin{array}{l}\text { Asam } \\
\text { lemak } \\
\text { ester }\end{array}$ \\
\hline 10.23 & 93 & 2 & $\begin{array}{l}\text { Hexade- } \\
\text { canoid acid }\end{array}$ & $\begin{array}{l}\text { Asam } \\
\text { lemak } \\
\text { ester }\end{array}$ \\
\hline 58.38 & 94 & 3 & $\begin{array}{l}\text { Octade- } \\
\text { canoic acid }\end{array}$ & $\begin{array}{l}\text { Asam } \\
\text { lemak } \\
\text { ester }\end{array}$ \\
\hline
\end{tabular}

Hasil identifikasi senyawa bioaktif berdasarkan hasil pada tabel 3 membuktikan bahwa terdapat asam lemak ester pada kultur hasil elisitasi dengan MeJa konsentrasi 0.5 mM selama 8 hari. Hal tersebut mengidentifikasikan bahwa dominansi asam lemak ester pada kultur hasil elisitasi dan memiliki kandungan senyawa berbeda dibandingkan dengan control tanpa perlakuan. 


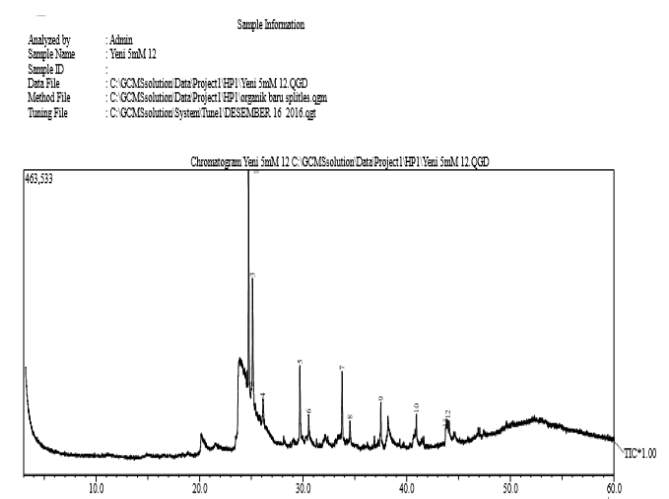

Gambar 9.Kromatogram ekstrak etil asetat suspensi sel jeruk purut (Citrus hystrix DC.) elisitasi MeJa $5 \mathrm{mM}$; 8 hari perlakuan.

Gambar 9 menunjukkan hasil kromatogram ekstrak etil asetat suspensi sel jeruk purut dengan penambahan elisitor MeJa konsentrasi $5 \mathrm{mM}$ dengan 8 hari perlakuan. Terdapat 12 peak hasil pada ekstrak hasil elisitasi dengan MeJa konsentrasi $5 \mathrm{mM}$ dengan umur perlakuan selama 8 harTabel 4 . Profil senyawa bioaktif hasil analisis GC-MS ekstrak etil asetat suspensi sel jeruk purut (Citrus hystrix DC.) perlakuan MeJa konsentrasi $5 \mathrm{mM}$ dan waktu panen hari ke-8 setelah perlakuan.

Tabel 4. Profil senyawa bioaktif hasil analisis GC-MS ekstrak etil asetat suspensi sel jeruk purut (Citrus hystrix DC.) perlakuan MeJa konsentrasi $5 \mathrm{mM}$ dan waktu panen hari ke-8 setelah perlakuan.

\begin{tabular}{cccll}
\hline $\begin{array}{c}\text { Peak } \\
\text { Area } \\
\text { (\%) }\end{array}$ & $\begin{array}{c}\text { SI } \\
\text { (\%) }\end{array}$ & $\begin{array}{c}\text { No. } \\
\text { Peak }\end{array}$ & $\begin{array}{c}\text { Nama } \\
\text { Senyawa }\end{array}$ & Golongan \\
\hline 28.92 & 79 & 1 & Germacrane A A & $\begin{array}{l}\text { Sesqui- } \\
\text { terpene }\end{array}$ \\
\hline 21.55 & 94 & 3 & Nonadecane & $\begin{array}{l}\text { Asam } \\
\text { lemak ester }\end{array}$ \\
\hline 3.68 & 85 & 4 & Decane & $\begin{array}{l}\text { Asam } \\
\text { lemak ester }\end{array}$ \\
\hline 12.83 & 94 & 5 & Eicosane & $\begin{array}{l}\text { Asam } \\
\text { lemak ester }\end{array}$ \\
\hline 2.41 & 88 & 6 & Hexadecane & $\begin{array}{l}\text { Asam } \\
\text { lemak ester }\end{array}$ \\
\hline 9.12 & 91 & 7 & Heptadecane & $\begin{array}{l}\text { Asam } \\
\text { lemak ester }\end{array}$ \\
\hline
\end{tabular}

\begin{tabular}{cccll}
\hline 3.22 & 88 & 8 & Octadecane & $\begin{array}{l}\text { Asam } \\
\text { lemak ester }\end{array}$ \\
\hline 3.68 & 91 & 9 & Heneicosane & $\begin{array}{l}\text { Asam } \\
\text { lemak ester }\end{array}$ \\
\hline 2.95 & 89 & 10 & Hexadecane & $\begin{array}{l}\text { Asam } \\
\text { lemak ester }\end{array}$ \\
\hline 6.66 & 73 & 11 & Phthalic acid & $\begin{array}{l}\text { Asam } \\
\text { lemak ester }\end{array}$ \\
\hline 2.62 & 76 & 12 & $\begin{array}{l}\text { Methyl- } \\
\text { nonadecane }\end{array}$ & $\begin{array}{l}\text { Asam } \\
\text { lemak ester }\end{array}$ \\
\hline
\end{tabular}

Berdasarkan tabel 4 diperoleh bahwa ada 11 jenis senyawa yang teridentifikasi pada hasil kromatogram. Dibandingkan dengan hasil senyawa kontrol tanpa perlakuan terdapat perbedaan yaitu munculnya germacrane-A yang merupakan senyawa golongan sesquiterpen dengan dominasi senyawa dalam jumlah tinggi (28,92\% peak area).

Berdasarkan hasil penelitian, senyawa metabolit sekunder yang berpotensi sebagai antikanker diperoleh dengan elisitasi dengan metil jasmonat dengan konsentrasi 0,05 mM. Prospek kedepan dari penelitian dapat menjadi agen obat herbal baru yang potensial dan relatif aman, khususnya untuk pengobatan kanker payudara.

\section{KESIMPULAN}

Kultur suspensi kalus jeruk purut mempunyai 3 jenis bentuk sel yaitu: bulat, koma dan panjang. Pemberian MeJa terhadap kultur suspensi kalus jeruk purut dapat menaikkan kandungan senyawa bioaktif ekstrak kultur sel suspensi kalus jeruk purut yaitu pada konsentrasi perlakuan 0,05 mM MeJa menghasilkan senyawa golongan 
terpenoid (Germacrane-A) yang potensi antikanker.

\section{DAFTAR PUSTAKA}

Abd El-Mawla, AMA. 2012. Influence of Certain Abiotic Elicitors on Production of anthraquinones in Cell Culture of Rubia tinctorum. Spatula DD. 2(2), 89-94.

Ali, G., Hadi, FZ., Tariq, AM., and Khan, MA. 2007. Callus induction and in vitro complete plant regeneration of different cultivars of tobacco (Nicotiana tabacum L.) on media of different hormonal concentrations. Biotechnol. 6: 561-566.

Ampasavate, C., Okonogi, S and Anuchapreeda, S. 2010. Cytotoxicity of extracts from fruit plants againts leukemic cell lines. African Journal of Pharmacy and Pharmacology. 4(1): 013-021.

Aziman, NN., Abdullah, ZM., Noor, KS., Zulkifli., and Kamarudin, WSSD. 2012. Phytochemical Constituents and In Vitro Bioactivity of Ethanolic Aromatic Herb Extracts (Kandungan Fitokimia dan Bioaktiviti In Vitro Etanol Ekstrak Aromatik Herba). Sains Malaysiana. 41(11): 1437.

Baradero, M, dkk.(2007). Seri Askep pada Klien Kanker. EGC, Jakarta.

Butryee, C., Sungpuag, P., and Chitchumroonchokchai, C. 2009. Effect of Processing on the Flavonoid Content and Antioxidant Capacity of Citrus hystrix Leaf. Int. J. Food Sci. Nutr. 2: 162-174.

Baguley, BC. 2010. Multidrug Resistance Mechanisms in Cancer. Molecular Biotechnology. 46(3): 308-316.

Bintang, M. 2010. Biokimia: Teknik penelitian. Erlangga. Jakarta Hal. 166-168, 198-199.

Butryee, C., Sungpuag, P., and Chitchumroonchokchai, C. 2009. Effect of Processing on the Flavonoid Content and Antioxidant Capacity of Citrus hystrix Leaf, Int. J. Food Sci. Nutr. 2009. 2: 162-174
Chanthaphon, S., Chanthachum, S., Hongpattarakere, T. 2008. Antimicrobial activities of essential oils and crude extracts from tropical Citrus spp. against food related microorganism. J Sci Technol. 30: 125-131.

Constabel, F. 1984. Callus Culture: Induction and Maintenance. Academic Press, Inc. Florida. p. 208-210.

Dalimartha, S. 2006. Atlas tumbuhan obat Indonesia, Vol 2. Niaga Swadaya. Jakarta. Hal. 93-95.

Day, RA., and Underwood, AL. 1998. Quantitative Analysis 6 ${ }^{\text {th }}$ Ed. Prentice Hall, Inc. New York. 480-489, 671

Deb, CR., and Imchen, T. 2010. An Efficient In Vitro Hardening Technique of Tissue Culture Raised Plants. Department of Botany, Nagaland University. India.

Hendaryono., Sriyanti, DP dan Wijayani, A. 1994. Teknik Kultur Jaringan. Kanisuis, Yogyakarta

Hidayat, S., Wahyuni, S dan Anda, S. 2008. Seri Tumbuhan Obat Berpotensi Hias. Elex Media Komputindo. Jakarta. Hal. 10-13.

Hutadilok-Towatana, NP., Chaiyamutti, K., Panthong, W., Mahabusarakam, V., Rukachaisirikul. 2006. Antioxidative and Free Radical Scavenging Activities of Some Plants Used in Thai Folk Medicine. Pharm. Biol. 44(3): 221-228.

Indrianto, A. 2003. Kultur Jaringan Tumbuhan. Fakultas Biologi, Universitas Gadjah Mada. Yogyakarta. Hal. 71-74.

Indrianto, AE., Semarti, dan Suyono, EA. 2014. Petunjuk praktikum teknik kultur jaringan tumbuhan. Fakultas Biologi, UGM Yogyakarta. Hal. 4-9.

Lambert, DG. 2004. Drugs and Receptors, Oxford Journal, 4(6): 181-184. http://ceaccp.oxfordjournals.org/content/4/ 6/181.full, 23/09/2016.

Mukkun, L. 2002. Pengaruh Aplikasi Metil Jasmonat Terhadap Perkembangan Warna dan Produksi Senyawa-Senyawa Aroma 
Volatil pada Buah Strawberri, Prosiding Seminar Nasional Teknologi Inovatif Pascapanen untuk Pengembangan Industri Berbasis Pertania. Fakultas Pertanian Undana. Hal. 811-821.

Muryanti, S., dan Anggarwulan, E. 2005. Pertumbuhan dan Produksi Reserpin Kalus Pule Pandak (Rauvolfia serpentina (L.)Bentham ex. Kurz.) pada Pemberian Metil Jasmonat secara in vitro. Bioteknologi. 2(2): 58-64.

Namdeo, AG. 2007. Plant Cell Elicitation for Production of Secondary Metabolites: A ReviewPharmacognosy Reviews. 1(1): 69-79.

NorOM. 1999. Volatile aroma compounds in Citrushystrix oil. J Trop Agric and Food Sci. 27(2): 225-229.

Ramdan, RN., Handaji, H., Beyahia., and Ibriz, M. 2014. Influence of growth regulators on callus induction from embryos of five citrus rootstocks. (73): 5959-5965.

Rudus, I., Kepczyhski, J., and Kepczyhska, E. 2001. The Influence of the Jasmonates and Absisic Acid on Callus Growth and Somatic Embryogenesis in Medicago sativa L. Tissue Culture. Acta Physiologiae Plantarum. 23(1): 103-107.

Salisbury, FB., and Ross, CW. 1995. Fisiologi Tumbuhan, Jilid 1, diterjemahkan oleh Diah R. Lukman, Sumaryono. Penerbit ITB, Bandung. Hal. 7-9, 11-20.
Santoso, U., and Nursandi, F. 2002. Kultur Jaringan Tanaman. Universitas Muhammadiyah Malang, Malang.

Silalahi, J. 2006. Makanan fungsional. Kanisius, Yogakarta. Hal. 14-17.

Smith, RH. 2012. Plant Tissue Culture: Techniques and Experiments. Academic Press. United States of America. p. 1-3.

Steenis, CGGJ. 2003. Flora Untuk Sekolah di Indonesia. PT Pradnya Paramita. Jakarta.

Vasconsuelo, A., and Boland, R. 2006. Molecular Aspects of the Early Stages of Elicitation of Secondary Metabolites in Plants. Plant Science. 172 (7): 861-875.

Waikedrea, J., Dugayb, A., Barrachinac, I., Herrenknechtc, C., Cabaliona, P., Fournet, A. 2010. Chemical Composition and Antimicrobial Activity of the Essential Oils from New Caledonian Citrus macroptera and Citrus hystrix. Chem Biodivers. 7: 871-877.

Wattimena. 1991. Farmakodinamik dan Terapi antibiotik. Gajah Mada University. Yogakarta.

Zhao, J., Davis, LC., and Verpoorte, R. 2005. Elicitor Signal Transduction Leading to Prroduction of Plant Secondary Metabolites, Biotechnology Advance. 23: 283-333. 